\title{
PENGARUH PENGENDALIAN INTERNAL PENERIMAAN DAN PENGELUARAN KAS TERHADAP KECURANGAN AKUNTANSI PADA PT. NAGA HARI UTAMA MEDAN
}

\author{
Syaharman \\ Universitas Dharmawangsa \\ syaharman1964@gmail.com
}

\begin{abstract}
The purpose of this study is to find out the influence of internal controls on accounting fraud that occurs in the company. If the internal control of a company is weak then the possibility of errors and fraud is greater. Conversely, if the internal controls are strong, then the possibility of fraud can be reduced. The effectiveness of internal control has a great influence in efforts to prevent the tendency of accounting fraud, with internal control, checking will occur automatically on one's work by others. The instruments used in this study are closed questionnaires, the questionnaires used are to net data on internal control of cash receipts and internal control of each respondent's cash expenditure against accounting fraud. Data collection is used by running a questionnaire containing questions that have been prepared in advance and answers related to research problems.

The results of the study obtained and at the same time the conclusion of this study include that from the results of the evaluation in adjusted $R$ Square number 0.641, this means that $64.1 \%$ of the variation in accounting fraud can be influenced by internal control factors of cash receipts and internal control of cash expenditures, while $35.9 \%$ is influenced by other factors. From the results of the simultaneous test obtained seen Fhitung value of 44,776> Ftabel 3.18 with a significant level of $0.000<0.05$, it can be concluded that the hypothesis (HI) can be accepted, namely internal control of cash receipts and internal control of cash expenditures together positively and significantly on accounting fraud at PT. Naga Hari Utama Medan. On the partial test the effect of internal control of cash receipts on accounting fraud obtained the value of $t$-calculate $=9,443>t$ table 2,000 with a significant $0.000<0.005$, it was concluded ho was rejected and $\mathrm{HI}$ received, which means internal control of cash receipts positively and significantly partially on accounting fraud. Furthermore, the results of partial testing of the effect of internal control of cash expenditures against accounting fraud obtained a value of $t$-calculate $=2,858>t$-table 2,000 with a significant $0.000<0.005$, then concluded Ho was rejected and $H 1$ received, which means internal control of cash expenditures positively and significantly partially on accounting fraud at PT. Naga Hari Utama Medan.
\end{abstract}

Keywords: Internal Control, Accounting Fraud

ABSTRAK : Tujuan penelitian ini adalah untuk mengetahui pengaruh pengendalian internal terhadap kecurangan akuntansi yang terjadi diperusahaan. Jika pengendalian internal suatu perusahaan lemah maka kemungkinan terjadinya kesalahan dan kecurangan semakin besar. Sebaliknya, jika pengendalian internalnya kuat, maka kemungkinan terjadinya kecurangan dapat diperkecil. Keefektifan pengendalian internal mempunyai pengaruh yang besar dalam upaya pencegahan kecenderungan kecurangan akuntansi, dengan adanya pengendalian internal maka pengecekan akan terjadi secara otomatis terhadap pekerjaan seseorang oleh orang lain. Instrumen yang digunakan dalam penelitian ini adalah angket tertutup, angket yang digunakan adalah untuk menjaring data pengendalian internal penerimaan kas dan pengendalian internal pengeluaran kas setiap responden terhadap kecurangan akuntansi. Pengumpulan data digunakan dengan cara menjalankan angket berisikan pertanyaan-pertanyaan yang telah dipersiapkan sebelumnya serta jawaban yang berhubungan dengan masalah penelitian. Hasil penelitian yang diperoleh dan sekaligus menjadi kesimpulan penelitian ini antara lain bahwa Dari hasil evaluasi di dapat angka adjusted $R$ Square 0,641, hal ini berarti adalah sebesar $64.1 \%$ variasi kecurangan akuntansi dapat dipengaruhi oleh faktor pengendalian internal penerimaan kas dan pengendalian internal 
pengeluaran kas, sedangkan $35.9 \%$ dipengaruhi oleh faktor lain.Dari hasil uji serempak didapat dilihat nilai Fhitung sebesar 44,776 > Ftabel 3,18 dengan taraf signifikan sebesar 0,000 < 0,05 maka dapat disimpulkan hipotesis (H1) dapat diterima yaitu pengendalian internal penerimaan kas dan pengendalian internal pengeluaran kas secara bersama-sama berpengaruh positif dan signifikan terhadap kecurangan akuntansi pada PT. Naga Hari Utama Medan. Pada uji parsial pengaruh pengaruh pengendalian internal penerimaan kas terhadap terhadap kecurangan akuntansi didapat nilai $t$-hitung $=9,443>t$-tabel 2,000 dengan signifikan 0,000 <0,005, maka disimpulkan Ho ditolak dan $\mathrm{Hl}$ diterima, yang artinya pengendalian internal penerimaan kas berpengaruh positif dan signifikan secara parsial terhadap kecurangan akuntansi. Selanjutnya, hasil pengujian parsial pengaruh pengendalian internal pengeluaran kas terhadap kecurangan akuntansi didapat nilai t-hitung $=2, .858>t$-tabel 2,000 dengan signifikan 0,000 <0,005, maka disimpulkan Ho ditolak dan $\mathrm{Hl}$ diterima, yang artinya pengendalian internal pengeluaran kas berpengaruh positif dan signifikan secara parsial terhadap kecurangan akuntansi pada PT. Naga Hari Utama Medan.

Kata kunci : Pengendalian Internal, Kecurangan Akuntansi

\section{Pendahuluan}

Jika diamati kecurangan yang banyak terjadi dalam banyak bidang tidak terlepas pada adanya keinginan untuk mengambil hak orang lain dan mementingkan kepentingan pribadi atau kelompok lalu menjadi pembenaran bahwa kecurangan merupakan hal biasa yang boleh dilakukan (rationalization), dan adanya kesempatan untuk melakukan kecurangan.

Demikian halnya dengan kecurangan dalam bidang akuntansi. Produk akhir dari proses pengolahan data akuntansi adalah informasi akuntansi yang tertuang dalam laporan keuangan. Dalam mengartikan angka-angka yang tercantum dalam laporan keuangan, pengguna laporan keuangan perlu berhati-hati karena kemungkinan terjadinya bisa dalam penyampaian informasi. Kemungkinan bahwa laporan keuangan disusun dengan itikad tidak baik (sengaja dilakukan) dengan tujuan tertentu. Jika faktor kecurangan terjadi dalam penyusunan laporan keuangan dapat dipastikan laporan keuangan disajikan tidak wajar.

Banyaknya kasus kecurangan diakibatkan karena tidak adanya sistem pengendalian internal sehingga lemahnya pengawasan atau kontrol, tidak adanya kejujuran, peraturan dan kinerja kerja lemah sehingga para pembuat kejahatan leluasa dapat melakukan aksinya. Selain itu kecurangan juga bisa berhubungan dengan karakter manusia itu sendiri. Karakter manusia dapat dilihat dari kepribadian dan pola pikir mereka yang menyarankan bahwa kejujuran dan keadilan itu sangatlah penting dan tidak boleh dihilangkan dan harus ditingkatkan dan dipertahankan agar bisa memondasi diri sendiri untuk tidak melakukan kecurangan.
Pengendalian adalah pengawasan atas tugas dengan membandingkan hasil dan sasaran secara teratur serta menyesuaikan usaha (kegiatan) dengan hasil pengawasan dan pengendalian. Sistem pengendalian internal merupakan suatu rangkaian dari kebijakankebijakan dan prosedur-prosedur yang diciptakan untuk memberikan jaminan yang memadai untuk tercapainya tujuan organisasi.

Dengan adanya sistem pengendalian internal, diharapkan ada suatu petunjuk tertulis yang jelas, dilakukan pemeriksaan atas ketaatan terhadap petunjuk. Bila ada penyimpangan, harus ditindaklanjuti dengan penelitian lanjutan. Bisa jadi memang kebijakan tadi sulit diimplementasikan atau sebaliknya staf pelaksananya tidak patuh.

Tindakan kecurangan dapat dipengaruhi adanya sistem pengendalian internal dan monitoring oleh atasan. Untuk menangani masalah kecurangan akuntansi, diperlukan monitoring, untuk mendapatkan hasil monitoring yang baik, diperlukan pengendalian internal yang efektif. Pengendalian internal yang baik memungkinkan manajemen siap menghadapi perubahan ekonomi yang cepat, persaingan, pergeseran permintaan pelanggan serta restrukturasi untuk kemajuan yang akan datang. Untuk menangani masalah kecurangan akuntansi, diperlukan monitoring, untuk mendapatkan hasil monitoring yang baik, diperlukan pengendalian internal yang efektif.

\subsection{Pengertian Pengendalian Internal}

Sistem pengendalian internal merupakan istilah yang telah umum dan banyak digunakan berbagai kepentingan. Istilah Pengendalian intern diambil dari terjemahan istilah "internal 
control" meskipun demikian penulis menterjemahkan sebagai pengawasan intern, untuk istilah tersebut hal ini tidaklah menjadi masalah karena tidak mengurangi pengertian sistem pengendalian internal secara umum.

Pengendalian internal yang baik harus meliputi seluruh struktur organisasi sampai serinci mungkin, tidak hanya mencakup kegiatan atau aktifitas akuntansi dan keuangan saja, tetapi juga meluas sampai pada aspek operasi perusahaan, seperti peningkatan efisiensi kerja dan analisa seberapa jauh kegiatan sistem dan prosedur yang digariskan perusahaan untuk dilaksanakan, untuk mencegah dan mengurangi kemungkinan penyelewengan dan kecurangan yang akan terjadi.

Menurut George H. Bodnar, William S, Hopwood (2008:15), "Sistem pengendalian internal yang terintegrasi, berhubungan dan saling mendukung satu sama lainnya”.

Baridwan (2009:13) menyatakan bahwa "Pengendalian intern (internal control) memiliki pengertian secara sempit dan luas. Dalam pengertian sempit pengawasan intern merupakan pengecekan penjumlahan, baik penjumlahan mendatar (crossfooting) maupun penjumlahan menurun (footing). Dalam artian yang luas, pengawasan intern tidak hanya meliputi pekerjaan pengecekan tetapi meliputi semua alat-alat yang digunakan manajemen untuk mengadakan pengawasan".

Rama dan Jones (2011:132) menyatakan pengendalian intern sebagai berikut: Pengandalian internal (internal control) adalah suatu proses, yang dipengaruhi oleh dewan direksi entitas, manajemen, dan personel lainnya, yang dirancang untuk memberikan kepastian yang beralasan terkait dengan pencapaian sasaran kategori sebagai berikut: efektivitas dan efisiensi operasi; keandalan pelaporan keuangan; dan ketaatan terhadap hukum dan peraturan yang berlaku.

Menurut Kosasih (2008:115), menyatakan pengertian pengendalian internal dalam arti luas dapat dibagi menjadi dua yaitu pengendalian administratif dan pengendalian akuntansi. Pengendalian administrasi meliputi rencana organisasi dan semua cara serta prosedurprosedur yang berhubungan dengan efisiensi usaha dan ketaatan terhadap kebijakan pimpinan perusahaan.

Bagi manajemen, kebijakan ini dirancang khusus untuk memastikan bahwa pencapaian tujuan perusahaan tidak akan mengalami hambatan atau kalau bisa mungkin lebih cepat.

Bila ada penyimpangan, harus ditindaklanjuti dengan penelitan lanjutan. Bisa jadi memang kebijakan tadi sulit diimplementasikan atau sebaliknya staf pelaksananya tidak patuh terhadap kebijakan perusahaan.

Krismiaji (2010:217), di lingkungan perusahaan, pengendalian internal didefinisikan sebagai suatu proses yang diberlakukan oleh pemimpin secara keseluruhan, dirancang untuk memberi suatu keyakinan akan tercapainya tujuan perusahaan yang secara umum dibagi menjadi tiga katagori:

a. Keefektifan dan keefesiensi operasional perusahaan

b. Pelaporan keuangan yang handal

c. Kepatuhan terhadap prosedur dan peraturan yang diberlakukan

Pengendalian internal juga harus memiliki unsur-unsur pokok yaitu struktur organisasi, sistem wewenang dan prosedur pencatatan, pelaksanan kerja yang sehat, dan karyawan yang berkualitas. Pengendalian internal ini berguna untuk mengarahkan perusahaan pengolahan kasnya tetap dalam tujuan yang benar yaitu ekonomis, efektif dan efisien.

\subsection{Tujuan Sistem Pengendalian Internal}

Anastasia dan Lilis (2011:30), sistem pengendalian internal dirancang oleh manajemen menjadi sesuatu yang melekat dalam setiap keputusan menajemen. Tujuan sistem pengendalian internal adalah sebagai berikut :

a. Menjaga kekayaan perusahaan.

b. Mengecek ketelitian dan dapat dipercaya tidaknya data akuntansi.

c. Mendorong efisiensi perusahaan.

d. Mendorong dipatuhinya kebijakan manajemen

Jadi, menurut tujuannya sistem pengawasan intern tersebut dapat dibagi dua macam, sistem pengawasan akuntansi dan sistem pengawasan administrasi.

Sistem pengawasan akuntansi, yang merupakan bagian dari sistem pengawasan internal, meliputi struktur organisasi, metode dan ukuran-ukuran yang dikoordinasikan terutama untuk menjaga kekayaan organisasi dan mengecek ketelitian dan dapat dipercaya tidaknya data akuntansi. Sistem pengawasan akuntansi yang baik akan menjamin keamanan kekayaan para investor dan kreditur yang 
ditanamkan dalam perusahaan dan akan menghasilkan laporan keuangan yang dapat dipercaya.

Menurut Widjaya (2010:36), laporan keuangan yang disajikan berdasarkan data-data yang diperoleh melalui sistem pengawasan akuntansi yang baik akan bertujuan :

a. Untuk memberikan informasi keuangan mengenai aktiva dan kewajiban serta modal perusahaan yang dapat dipercaya.

b. Untuk memberikan informasi keuangan mengenai perubahan aktiva netto (aktiva dikurangi kewajiban) suatu perusahaan yang timbul dari kegiatan usaha dalam rangka memperoleh laba.

c. Untuk memberikan informasi keuangan yang membantu para pemakai laporan dalam menaksir potensi perusahaan dalam menghasilkan laba.

d. Untuk memberikan informasi penting lainnya mengenai perubahan dalam aktiva dan kewajiban suatu perusahaan, seperti informasi mengenai aktivitas pembiayaan dan investasi.

e. Untuk mengungkapkan sejauh mungkin informasi mengenai kebijaksanaan akuntansi yang dianut perusahaan.

Sistem pengendalian intern berusaha mencapai salah satu tujuannya yaitu pengamanan asset atau harta kekayaan organisasi. Tujuan lain dari pengendalian intern adalah menjamin bahwa data yang diinformasikan ke pihak manajemen adalah data yang tingkat keandalannya tinggi hingga kemungkinan manajemen mengambil keputusan yang keliru karena data yang salah dapat dijaga pada tingakat minimal. Pengendalian intern yang baik dapat memberikan jaminan tingkat keandalan dan ketelitian data yang tinggi.

\subsection{Sistem Pengendalian Internal Penerimaan Kas}

Sumber penerimaan kas yang utama akan tergantung dari bidang usaha suatu perusahaan.Prosedur pengendalian penerimaan kas didalam perusahaan perlu direncanakan sedemikian rupa, sehingga kemungkinan tidak tercatatnya penerimaan dan kemungkian tidak diterimanya penerimaan kas yang seharusnya diterima dapat dikurangi sekecil mungkin. Pada dasarnya untuk dapat menghasilkan sistem pengendalian yang baik atas penerimaan kas, prosedur yang bersangkutan dengan kas dirancang sedemikian rupa.

Pengendalian internal penerimaan kas menurut Hery (2008:169) yaitu:

a. Hanya karyawan tertentu saja yang secara khusus ditugaskan untuk menangani penerimaan kas.

b. Adanya pemisahan tugas antara individu yang menerima kas, mencatat atau membukukan penerimaan kas, dan yang menyimpan kas.

c. Setiap transaksi penerimaan kas harus didukung oleh dokumen (sebagai bukti transaksi). Seluruh uang kas harian yang diterima perusahaan dipegang oleh departemen kasir.

d. Uang kas hasil penerimaan harian atau hasil penagihan piutang dari pelanggan harus disetor ke bank setiap hari oleh departemen kasir.

e. Dilakukannya pengecekan independen atau verufikasi internal.

f. Mengikat karyawan yang menangani penerimaan kas dengan uang pertanggungan. Berdasarkan uraian di atas dapat disimpulkan bahwa pengendalian internal penerimaan kas merupakan transaksi penerimaan kas harus didukung oleh dokumen (sebagai bukti transaksi) dengan dilakukan pengecekan independen atau verufikasi internal.

\subsection{Sistem Pengendalian Internal Pengeluaran Kas}

Menurut Mulyadi (2008:543) "Sistem Akuntansi Pengeluaran Kas adalah suatu catatan yang dibuat untuk melaksanakan kegiatan pengeluaran baik dengan cek maupun dengan uang tunai yang digunakan untuk kegiatan umum perusahaan"

Kas mungkin saja dikeluarkan untuk berbagai macam tujuan, seperti untuk membayar beban dan kewajiban, atau untuk membeli asset. Umumnya, pengendalian internal atas pengeluaran kas lebih efektif melalui cek, dari pada dengan uang tunai. Pengecualian berlaku untuk jumlah incidental (pengeluaran-pengeluaran kecil yang tidak selalu terjadi) yang dibayar dengan kas kecil.

Menurut Mulyadi (2008:517), sistem pengendalian internal dalam sistem pengeluaran kas adalah:

1. Fungsi penyimpanan kas harus terpisah dari fungsi akuntansi. 
2. Transaksi pengeluaran kas tidak boleh dilakasanakan sendiri oleh bagian kasa dari sejak awal sampai akhir, tanpa campur tangan dari fungsi yang lain

3. Pengeluaran kas harus mendapatkan otorisasi dari pejabat yang berwenang.

4. Pembukuan dan penutupan rekening bank harus mendapatkan persetujuan dari pejabat yang berwenang.

5. Pencatatan dalam jurnal pengeluaran kas atau dalam pencatatan tertentu dalam register cek harus didasarkan atas bukti kas keluar yang telah mendapatkan otorisasi dari pejabat yang berwenang dan yang dilampiri dengan dokumen pendukung yang lengkap.

6. Saldo kas yang ada ditangan harus dilindungi dari kemungkinan pencurian atau penggunaan yang tidak semestinya.

7. Dokumen dasar dan dokumen pendukung transaksi pengeluaran kas harus diberi cap "Lunas" oleh bagian kasa setelah tansaksi pengeluaran kas dilakukan.

8. Penggunaan rekening koran bank, yang merupakan informasi dari pihak ketiga, untuk mengecek ketelitian kas oleh fungsi yang tidak terlibat dalam pencatatan dan penyimpanan kas.

9. Semua pengeluaran kas yang berjumlah besar harus dilakukan dengan cek atas nama pemindah buku.

10.Secara periodik diadakan pencocokan jumlah fisik kas yang ada ditangan dengan jumlah kas menurut catatan.

11.Kasir diasuransikan

12.Kasir harus dilengkapi dengan alat-alat yang mencegah terjadinya pencurian terhadap kas yang ada ditangan seperti mesin register kas dan lemari besi.

13.Semua nomor cek harus dipertanggungjawabkan bagian kasir.

Bedasarkan uraian di atas, sistem pengendalian internal dalam sistem pengeluaran kas terdiri dari penyimpanan kas, transaksi pengeluaran kas, pengeluaran kas, pembukuan dan penutupan rekening bank, pencatatan dalam jurnal, saldo kas yang ada ditangan harus dilindungi, dokumen dasar dan dokumen pendukung transaksi, penggunaan rekening koran bank, pengeluaran besar dengan cek, mencegah terjadinya pengeluaran kas dan semua nomor cek harus dipertanggungjawabkan.

\subsection{Kecurangan Akuntansi}

Menurut Suprajadi (2009:45), dalam akuntansi, dikenal dua jenis kesalahan yaitu kekeliruan (error) dan kecurangan (fraud). Kedua jenis kesalahan ini dapat bersifat material dan non material. Perbedaan antara kedua jenis kesalahan ini hanya dibedakan oleh jurang yang sangat tipis, yaitu ada atau tidaknya unsur kesengajaan. Untuk itu dibutuhkan keahlian profesional untuk bisa membedakan antara kedua jenis kesalahan tersebut. Standarpun mengenali bahwa sering kali mendeteksi kecurangan lebih sulit dibandingkan dengan kekeliruan karena pihak manajemen atau karyawan akan berusaha menyembunyikan kecurangan itu.

Menurut Ikatan Akuntan Indonesia (2012) menjelaskan kecurangan akuntansi sebagai: (1) Salah saji yang timbul dari kecurangan dalam pelaporan keuangan yaitu salah saji atau penghilangan secara sengaja jumlah atau pengungkapan dalam laporan keuangan untuk mengelabuhi pemakai laporan keuangan, (2) Salah saji yang timbul dari perlakuan tidak semestinya terhadap aktiva (seringkali disebut dengan penyalahgunaan atau penggelapan) berkaitan dengan pencurian aktiva entitas yang berakibat laporan keuangan tidak disajikan sesuai dengan prinsip akuntansi yang berlaku umum di Indonesia.

Perlakuan tidak semestinya terhadap aktiva entitas dapat dilakukan dengan berbagai cara, termasuk penggelapan tanda terima barang/uang, pencurian aktiva, atau tindakan yang menyebabkan entitas membayar barang atau jasa yang tidak diterima oleh entitas. Perlakuan tidak semestinya terhadap aktiva dapat disertai dengan catatan atau dokumen palsu atau yang menyesatkan dan dapat menyangkut satu atau lebih individu di antara manajemen, karyawan, atau pihak ketiga.

Menurut Widjaya (2010:76), pada dasarnya terdapat dua tipe kecurangan, yaitu eksternal dan internal. Kecurangan eksternal adalah kecurangan yang dilakukan oleh pihak luar terhadap suatu perusahaan/entitas, seperti kecurangan yang dilakukan pelanggan terhadap usaha; wajib pajak terhadap pemerintah. Kecurangan internal adalah tindakan tidak legal dari karyawan, manajer dan eksekutif terhadap perusahaan tempat ia bekerja.

Dampak dan konsekuensi yang ditimbulkan oleh kecurangan akuntansi tidak dapat dihindarkan. Perusahaan akan menderita kerugian yang signifikan karena hal tersebut. 
Kecurangan akuntansi biasanya dipicu oleh perusahaan yang ingin agar laporan keuangannya terlihat baik. Selain itu, perusahaan juga ingin mengurangi persepsi di mata para calon investor bahwa perusahaannya beresiko. Saham perusahaan mungkin akan dinilai lebih tinggi jika investor menilai bahwa perusahaan tersebut memiliki tingkat resiko yang rendah, karena mereka tidak akan khawatir perusahaan akan bangkrut.

\subsection{Pengendalian Internal dengan Kecurangan Akuntansi}

Menurut Arens (2010:370), sistem pengendalian intern merupakan kebijakan dan prosedur yang dirancang memberikan manajemen kepastian yang layak bahwa perusahaan telah mencapai tujuan dan sasaran yaitu : reliabilitas pelaporan keuangan, efisiensi, dan efektivitas operasional, dan ketaatan pada hukum dan aturan.

Dari pernyataan tersebut dapat dlihat bahwa sistem pengendalian internal yang tidak efektif akan membuat seseorang lebih mudah untuk melakukan tindakan kecurangan yang akan merugikan perusahaan dan mengganggu keberlangsungan perusahaan, sehingga tujuan dari perusahaan tidak tercapai.

Menurut Widjaya (2010:226), dalam teori GONE yaitu teori yang mengemukakan empat faktor yang menyebabkan dan mendorong seseorang untuk melakukan kecurangan yaitu Greed (Keserakahan), Opportunity (Kesempatan), Need (Keinginan) dan Exposure (pengungkapan), menyatakan faktor yang sangat mendukung terjadinya kecurangan dalam suatu organisasi yaitu adanya opportunity (kesempatan).

Kecurangan akuntansi umumnya dilakukan karena adanya kesempatan dan peluang yang muncul akibat lemahnya pengendalian internal dalam perusahaan. Sistem pengendalian internal yang lemah, membuat seseorang tidak takut untuk melakukan tindakan yang merugikan perusahaan, karena tindakan yang mereka lakukan tidak terdeteksi oleh siapapun.

Sebaliknya, jika semakin baik system pengendalian internal dalam perusahaan maka tindakan kecurangan akuntansi akan sulit dilakukan, karena setiap kegiatan yang mereka lakukan telah dibatasi dan dikelola sebatas pada tanggung jawab mereka masing-masing terhadap tugasnya. Sehingga setiap kegiatan akan dikontrol oleh bagian lain, jika terjadi kecurangan, maka pihak lain akan mengetahuinya, sehingga setiap orang yang memiliki niat melakukan kecurangan dapat dicegah.

Dalam sebuah perusahaan, penerapan pengendalian internal sangat penting. Terutama pengendalian internal terhadap penerimaan dan pengeluaran kas, karena kas merupakan aktiva lancar yang paing likuid (cepat dijadikan uang dan dapat digunakan untuk membayar kewajiban perusahaan tanpa pembatasan). Kas memiliki karakteristik yang tidak dimiliki aktiva lancar lainnya, yaitu kas tidak mudah diidentifikasi pemiliknya, dapat diuangkan segera, mudah dibawa-bawa serta mudah untuk ditransfer dalam kurun waktu yang relatif cepat. Mengingat karakteristiknya, kas merupakan aktiva yang paling mudah disalahgunakan.

Oleh karenanya, bagian penerimaan dan pengeluaran kas di dalam suatu perusahaan harus dapat berfungsi dengan sebaik-baiknya untuk mencegah terjadinya penyalahgunaan dan penyelewengan terhadap kas. Manajemen mempunyai tanggung jawab paling utama dalam menjaga keamanan harta milik perusahaan serta menemukan dan mencegah terjadinya kesalahan dan penyelewengan ataupun pemborosan pada saat perusahaan beroperasi. Manajemen terhadap kas juga bertanggung jawab terhadap pembuatan perencanaan, melakukan prosedur atau otorisasi serta menetapkan dan mengawasi suatu kegiatan melalui pengendalian internal.

\section{METODE PENELITIAN}

Dalam pengumpulan data baik data primer dan data sekunder, peneliti menggunakan berbagai teknik pengumpulan data, yakni :

a. Menurut Arikunto (2010:231), "tinjauan kepustakaan (Library Research), yaitu penelitian yang dilakukan dengan cara mengumpulkan, membaca, dan mempelajari literatur dan buku-buku serta referensi yang relevan dengan permasalahan yang dikaji berguna dalam pembahasan".

b. Menurut Arikunto (2010:233), "tinjauan lapangan (Field Research), yaitu penelitian yang dilakukan dengan memperoleh data langsung di lapangan".

c. Menurut Indriantoro dan Supeno (2009:152), "wawancara merupakan teknik pengumpulan data dalam metode survey yang menggunakan pertanyaan secara lisan kepada subyek penelitian". Wawancara melakukan tanya jawab dengan pimpinan perusahaan dan para karyawan PT. Naga 
Hari Utama Medan yang bersangkutan untuk memberikan data atau informasi yang dibutuhkan dalam penelitian ini.

d. Menurut Sugiyono (2010:33), kuesioner (angket) yaitu tehnik pengumpulan data yang dilakukan dengan cara memberi seperangkat pertanyaan atau pertanyaan tertulis kepada responden untuk dijawab, dengan menggunakan Skala Likert, di mana setiap pertanyaan mempunyai 5 (lima) opsi yaitu:

e.

Tabel 1 Skala Likert

\begin{tabular}{|l|l|}
\hline \multicolumn{1}{|c|}{ Pertanyaan } & Bobot \\
\hline Sangat Setuju (SS) & 5 \\
\hline Setuju (S) & 4 \\
\hline Kurang Setuju (KS) & 3 \\
\hline Tidak Setuju (TS) & 2 \\
\hline Sangat Tidak Setuju (STS) & 1 \\
\hline
\end{tabular}

Berdasarkan skala likert, responden yang menjawab A (sangat setuju) dengan nilai 5, menjawab B (setuju) dengan nilai 4 , menjawab C (kurang setuju) dengan nilai 3, menjawab D (tidak setuju) dengan nilai 2 dan menjawab E (sangat tidak setuju) dengan nilai 1

\subsection{Tehnik Analisis Data}

Analisis data yang digunakan dalam penelitian ini adalah metode analisis statistik dengan bantuan software SPSS 19.0. Sebelum dianalisis, peneliti terlebih dahulu melakukan uji asumsi klasik sebelum melakukan pengujian hipotesis.

Uji asumsi klasik digunakan untuk mengetahui apakah hasil analisis regresi linier berganda yang digunakan untuk menganalisis dalam penelitian ini terbebas dari penyimpangan asumsi klasik yang meliputi uji normalitas, multikolinieritas, heteroskedastisitas dan autokorelasi. Adapun masing-masing pengujian tersebut dapat dijabarkan sebagai berikut:

\section{a. Uji Normalitas}

Uji Normalitas bertujuan untuk menguji apakah dalam model regresi, variabel dependen dan independen keduanya mempunyai distribusi normal atau tidak. Model regresi yang baik adalah memiliki distribusi data normal atau mendekati normal. Uji normalitas data dalam penelitian ini menggunakan aplikasi SPSS for Windows untuk pengujian terhadap data sampel tiap variabel. Untuk mendeteksi normalitas data melalui output grafik kurva normal $p-p$ plot. Suatu variabel dikatakan normal jika gambar distribusi dengan titik-titik data yang menyebar di sekitar garis diagonal, dan penyebaran titik-titik data searah mengikuti garis diagonal.

Selain menggunakan grafik p-plot, pengujian normalitas data juga dilakukan dengan menggunakan kurva histogram. Normalitas data bila dilihat dengan cara kurva histogram dapat ditentukan berdasarkan gambar kurva, yaitu bila bentuk kurva memiliki kemiringan yang cenderung seimbang baik pada sisi kiri maupun sisi kanan dan kurva berbentuk lonceng yang hampir sempurna.

b. Uji Multikolinearitas

Uji ini dimaksudkan untuk mendeteksi gejala korelasi antara variabel bebas yang satu dengan variable bebas yang lain. Asumsi multikolinearitas menyatakan bahwa variabel independen harus terbebas dari gejala multikolinearitas. Gejala multikolinearitas adalah gejala korelasi antar variabel independen. Gejala ini ditunjukkan dengan korelasi yang signifikan antar variabel independen. Apabila terjadi adanya gejala multikolinearitas, salah satu langkah untuk memperbaiki model adalah dengan menghilangkan variabel dari model regresi, sehingga bisa dipilih model yang paling baik. Multikolinearitas berarti ada hubungan linear yang "sempurna" (pasti) di antara beberapa atau semua variabel independen dari model regresi.

Uji Multikolinieritas dapat dilakukan dengan 2 cara yaitu dengan melihat VIF (Variance Inflation Factors) dan nilai tolerance. Jika VIF $>10$ dan nilai tolerance $<0,10$ maka tidak terjadi gejala multikolinieritas.

c. Uji Heteroskedastisitas

Uji Heteroskedastisitas bertujan menguji apakah dalam model regresi terjadi ketidaksamaan variance dari residual satu pengamatan ke pengamatan lain. Jika variance dari residual satu pengamatan yang lain. jika variance dari residual satu pengamatan ke pengamatan yang lain tetap maka disebut Homoskedastisitas dan jika berbeda disebut Heteroskedastisitas. Model regresi yang baik adalah Homoskedastisitas atau tidak terjadi Heteroskedastisitas. 


\section{Hasil Penelitian Dan Pembahasan 3.1. Uji Validitas}

Pengujian validitas dilakukan dengan one way analysis dengan menggunakan pendekatan uji validitas internal, yakni menguji validitas setiap butir pertanyaan, digunakan SPSS

- Berdasarkan hasil uji validitas terdapat di kolom Corrected Item-Total Correlation dari variabel pengendalian internal penerimaan kas, pengendalian internal pengeluaran kas, dan kecurangan akuntansi lebih besar dari 0,30 atau dengan kata lain seluruh pertanyaan dinyatakan valid.

\subsection{Uji Realibilitas}

Setelah dilakukan penelitian pengujian reabilitas dapat diketahui reabilitas variabel pengendalian internal penerimaan kas dengan alpha sebesar 0,961, pengendalian internal pengeluaran kas dengan alpha sebesar 0,822, variabel kecurangan akuntansi dengan alpha sebesar 0,837. Menurut Trihendradi (2011:217), "jika nilai reabilitas lebih besar dari yang dipersyaratkan 0.60 , maka intrumen tersebut reliable". Apabila dilihat dari tingkat reliabilitas intrumen penelitian di atas maka dapat disimpulkan intrumen penelitian in dapat diterima karena lebih besar dari 0,60.

\subsection{Uji Normalitas}

Uji normalitas bertujuan untuk menguji salah satu asumsi dasar analisis regresi berganda, yaitu variabel-variabel independen dan dependen harus berdistribusi normal atau mendekati normal. Untuk menguji apakah datadata yang dikumpulkan berdistribusi normal atau tidak dapat dilakukan dengan metode grafik dan statistik. Metode grafik yang handal untuk menguji normalitas data adalah dengan melihat normal probability plot dan histogram sehingga hampir semua aplikasi komputer statistik menyediakan fasilitas ini. Secara statistik, normalitas data dapat dilakukan dengan uji Kolmogorov-Smirnov.

Berdasarkan gambar $4.2 \mathrm{di}$ atas, nampak bahwa sebaran (pencaran) data berada di sekitar garis diagonal dan tidak ada yang terpencar jauh dari garis diagonal, sehingga asumsi normalitas dapat dipenuhi.

Berdasarkan gambar 4.3 di atas, nampak bahwa bentuk histogram menggambarkan data yang berdistribusi normal atau mendekati normal karena membentuk seperti lonceng (bell shaped), sehingga asumsi normalitas dalam penelitian ini dapat dipenuhi.
Berdasarkan tabel 4.10 terlihat bahwa nilai Kolmogorov-Smirnov berada diatas cut off value yang telah disepakati, yaitu 0.05 jadi $0.959>0.05$ maka disimpulkan data terdistribusi secara normal. Secara keseluruhan, dengan menggunakan metode grafik, dan statistik dapat dinyatakan bahwa asumsi normalitas dipenuhi dalam penelitian ini.

\subsection{Multikolinearitas}

Pengujian multikoliniearitas bertujuan untuk mengetahui ada tidaknya hubungan yang sempurna atau sangat tinggi antar variabel independen dalam model regresi. Konsekuensi dari adanya hubungan (korelasi) yang sempurna atau sangat tinggi antar variabel independen adalah koefisien regresi dan simpangan baku (standard deviation) variabel independen menjadi sensitif terhadap perubahan data serta tidak memungkinkan untuk mengisolir pengaruh individual variabel independent terhadap variabel dependen.Berdasarkan hasil tabel $4.11 \mathrm{di}$ atas dapat dilihat dikolom coefficients statistic yaitu pada kolom VIF. Nilai VIF untuk pengendalian internal penerimaan kas dan kepemimpinan transaksional sebesar 1.001, karena lebih kecil dari 5, maka dapat disimpulkan bahwa tidak terjadi masalah multikolinearitas pada model regresi.

\subsection{Uji Heteroskedastisitas}

Uji heteroskedastisitas bertujuan menguji apakah dalam model regresi terjadi ketidaksamaan variance dari residual satu pengamatan ke pengamatan yang lain. Jika variance dari residual satu pengamatan ke pengamatan yang lain tetap maka disebut homoskedastisitas dan jika berbeda disebut heteroskedastisitas. Model regresi yang baik adalah yang homoskedastisitas bukan heteroskedastisitas.Berdasarkan Gambar 4.4 di atas, nampak bahwa noktah-noktah terpencar dengan tidak membentuk pola seperti cerobong asap di sekitar garis diagonal (menyebar lalu menyempit atau sebaliknya), di atas dan di bawah angka 0 pada sumbu Y. Dinyatakan bahwa pada model regresi dalam penelitian ini terjadi homoskedastisitas daripada heteroskedastisitas.

\section{Pengujian Hipotesis}

Pengujian terhadap hipotesis yang dirumuskan dilakukan dengan menggunakan analisis regresi berganda baik secara parsial 
maupun simultan. Hipotesis null (Ho) adalah hipotesis yang menyebutkan antara variabel independent tidak berpengaruh terhadap variabel dependen. Hipotesis alternatif $(\mathrm{Ha})$ adalah hipotesis yang menyebutkan adanya pengaruh antara variabel independen dan dependen.

a. Uji Signifikansi Simultan (Uji F)

Dari tabel 4.15 didapat dilihat nilai Fhitung sebesar 44,776 > Ftabel 3,18 dengan taraf signifikan sebesar $0,000<0,05$ maka dapat disimpulkan hipotesis (H1) dapat diterima yaitu pengendalian internal penerimaan kas dan pengendalian internal pengeluaran kas secara bersama-sama berpengaruh positif dan signifikan terhadap kecurangan akuntansi pada PT. Naga Hari Utama Medan.

b. Uji Signifikansi Parsial (Uji-t)

Setelah dilakukan uji serempak (Uji-F) kemudian dilakukan uji parsial (Uji-t) untuk mengetahui pengaruh variabel bebas terhadap variabel terikat secara individu pada tingkat kepercayaan (confidence interval) $95 \%$ atau test of level pengujian hipotesis $5 \%$. Hasil uji parsial dapat dilihat tabel 4.16 di bawah ini.

Tabel 1

Coefficients $^{\mathrm{a}}$

\begin{tabular}{|c|c|c|c|c|c|}
\hline \multirow[t]{2}{*}{ Model } & \multicolumn{2}{|c|}{$\begin{array}{l}\text { Unstandardized } \\
\text { Coefficients }\end{array}$} & \multirow{2}{*}{$\begin{array}{c}\text { Standardized } \\
\text { Coefficients } \\
\text { Beta }\end{array}$} & \multirow[b]{2}{*}{$\mathrm{t}$} & \multirow[b]{2}{*}{ Sig. } \\
\hline & $\mathrm{B}$ & Std. Error & & & \\
\hline (Constant) & $\begin{array}{r}15,52 \\
0\end{array}$ & 4,597 & & 3,376 & ,001 \\
\hline Penerimaan kas & ,576 & ,061 & ,808 & 9,443 & ,230 \\
\hline Pengeluaran kas & ,074 & ,086 & ,073 & 2,858 & ,395 \\
\hline
\end{tabular}

\section{Pembahasan}

Dari tabel 1 dapat terlihat variabel bebas (independen) yang dimasukkan ke dalam model regresi variabel pengendalian internal penerimaan kas dan pengendalian internal pengeluaran kas signifikan hal ini dapat dilihat dari probabilitas signifikan untuk pengendalian internal penerimaan kas sebesar 0.23 dan pengendalian internal pengeluaran kas sebesar 0,395 dan nilai keduanya di atas 0,05 , maka Ho ditolak dan Ha diterima, jadi pengendalian internal penerimaan kas dan pengendalian internal pengeluaran kas dapat mempengaruhi kecurangan akuntansi.

Dari tabel $1 \mathrm{di}$ atas, didapat persamaan regresi linear berganda sebagai berikut : $\mathrm{Y}=$ $15.520+0.576(\mathrm{X} 1)+0.074(\mathrm{X} 2)$. Berikut adalah penjelasan dari persamaan regresi berganda yang terbentuk :

1) Pengaruh pengendalian internal penerimaan kas memiliki nilai t sebesar 9.433 nilai koefisien $\mathrm{b}$ sebesar 0.576, dan tingkat signifikan sebesar 0.230. Hal ini menandakan bahwa koefisien variabel (X1) pengaruh pengendalian internal penerimaan kas memiliki pengaruh positif sebesar 9.433 terhadap kecurangan akuntansi(Y), dengan tingkat signifikan sebesar 0,230. Artinya pengendalian internal penerimaan kas berpengaruh positif terhadap kecurangan akuntansi karena tingkat signifikansinya lebih besar dari 0,05 .

2) Pengendalian internal pengeluaran kas memiliki nilai $\mathrm{t}$ sebesar 2.858, nilai koefisien b sebesar 0.074, dan tingkat signifikan sebesar 0.395. Hal ini menandakan bahwa koefisien variabel (X2) yaitu pengendalian internal pengeluaran kas memiliki pengaruh positif terhadap kecurangan akuntansi $(\mathrm{Y})$ dengan tingkat signifikan 0.395. Artinya semakin tinggi pengendalian internal pengeluaran kas yang diberikan perusahaan maka semakin rendah kecurangan akuntansi.

3) Konstanta sebesar 15.520 berarti kecurangan akuntansi memiliki kemampuan untuk mempengaruhi faktor pengendalian internal penerimaan kas dan pengendalian internal pengeluaran kas sebesar konstanta meskipun variabel independennya bebas (nol).

Dari hasil pengujian regresi linier berganda $\mathrm{Y}=15.520+0.576(\mathrm{X} 1)+0.074(\mathrm{X} 2)$. Dari persamaan regresi dapat dijelaskan sebagai berikut: $\quad b_{0}=$ konstanta $=415.520$ menunjukkan besarnya nilai dari variabel kecurangan akuntansi (Y). Apabila variabel pengendalian internal penerimaan kas (X1), dan pengendalian internal pengeluaran kas (X2) sama dengan nol atau konstan, maka Y sebesar 48,399 . 
$b_{1}=$ koefisien regresi untuk pengendalian internal penerimaan kas $(\mathrm{X} 1)=0.576$ berdasarkan koefisien regresi pengendalian internal penerimaan kas (X1) sebesar 0.576 dan bertanda positif. Hal tersebut menunjukkan adanya perubahan dari variabel bebas terhadap variabel terikat.

$b_{2}=$ koefisien regresi untuk pengendalian internal pengeluaran kas $(\mathrm{X} 2)=0.074$. Berdasarkan koefisien regresi untuk pengendalian internal pengeluaran kas sebesar 0.074 dan bertanda negatif. Hal tersebut menunjukkan adanya perubahan dari variabel bebas terhadap variabel terikat secara signifikan.

Dari tabel 1 hasil pengujian parsial pengaruh pengendalian internal penerimaan kas terhadap kecurangan akuntansi didapat nilai t-hitung = 9,443 > t-tabel 2,000 dengan signifikan 0,000 < 0,005, maka disimpulkan Ho ditolak dan H1 diterima, yang artinya pengendalian internal penerimaan kas berpengaruh positif dan signifikan secara parsial terhadap kecurangan akuntansi pada PT. Naga Hari Utama.

Selanjutnya, hasil pengujian parsial pengaruh pengendalian internal pengeluaran kas terhadap kecurangan akuntansi didapat nilai thitung $=2, .858>$ t-tabel 2,000 dengan signifikan $0,000<0,005$, maka disimpulkan Ho ditolak dan H1 diterima, yang artinya pengendalian internal pengeluaran kas berpengaruh positif dan signifikan secara parsial terhadap kecurangan akuntansi pada PT. Naga Hari Utama.

\section{Kesimpulan}

Berdasarkan pembahasan hasil penelitian, penulis mengambil beberapa kesimpulan sebagai berikut:

a. Dari hasil evaluasi di dapat angka adjusted $R$ Square 0,641, hal ini berarti adalah sebesar $64.1 \%$ variasi kecurangan akuntansi dapat dipengaruhi oleh faktor pengendalian internal penerimaan kas dan pengendalian internal pengeluaran kas, sedangkan $35.9 \%$ dipengaruhi oleh faktor lain.

b. Dari hasil uji serempak didapat dilihat nilai Fhitung sebesar 44,776 > Ftabel 3,18 dengan taraf signifikan sebesar $0,000<0,05$ maka dapat disimpulkan hipotesis (H1) dapat diterima yaitu pengendalian internal penerimaan kas dan pengendalian internal pengeluaran kas secara bersama-sama berpengaruh positif dan signifikan terhadap kecurangan akuntansi pada PT. Naga Hari Utama.

c. Pada uji parsial pengaruh pengaruh pengendalian internal penerimaan kas terhadap terhadap kecurangan akuntansi didapat nilai t-hitung $=9,443>$ t-tabel 2,000 dengan signifikan $0,000<0,005$, maka disimpulkan Ho ditolak dan $\mathrm{H} 1$ diterima, yang artinya pengendalian internal penerimaan kas berpengaruh positif dan signifikan secara parsial terhadap kecurangan akuntansi. Selanjutnya, hasil pengujian parsial pengaruh pengendalian internal pengeluaran kas terhadap kecurangan akuntansi didapat nilai t-hitung $=2, .858>$ t-tabel 2,000 dengan signifikan $0,000<0,005$, maka disimpulkan Ho ditolak dan $\mathrm{H} 1$ diterima, yang artinya pengendalian internal pengeluaran kas berpengaruh positif dan signifikan secara parsial terhadap kecurangan akuntansi pada PT. Naga Hari Utama.

d. Dari penelitian yang telah dilakukan, diperoleh hasil bahwa pengendalian internal penerimaan kas mempunyai pengaruh terhadap kecurangan akuntansi di PT. Naga Hari Utama Medan. Pengaruh yang ditimbulkan adalah positif, yaitu semakin tinggi tingkat pengendalian internal penerimaan kas maka semakin rendah kecurangan akuntansi.

e. Berdasarkan hasil penelitian dapat diketahui bahwa kedua variabel bebas yang diteliti yakni pengendalian internal penerimaan kas dan pengendalian internal pengeluaran kas berpengaruh secara nyata terhadap kecurangan akuntansi. Hal tersebut berarti di PT. Naga Hari Utama Medan dengan variabel pengendalian internal penerimaan kas dan pengendalian internal pengeluaran kas adalah merupakan dua faktor penting dapat mempengaruhi kecurangan akuntansi.

\section{DAFTAR PUSTAKA}

Amin Widjaja Tunggal. 2010. Pemeriksaan Kecurangan (Fraud Auditing). Jakarta: Rineka Cipta.

Anastasia, Diana dan Setiawati, Lilis. 2011. Sistem Informasi Akuntansi. Yogyakarta: Andi.

Arens, Alura. A, 2010. Auditing dan Layanan Verifikasi. Jakarta: Gramedia

Bodnar. 2008. Sistem Akuntansi. Yogyakarta: Andi. 
Hery. 2008. Pengantar Akuntansi 1. Jakarta: Fakultas Ekonomi Universitas Indonesia.

Ikatan Akuntan Indonesia. 2012. Standar Akuntansi Keuangan. Jakarta: Salemba Empat.

Imam Ghozali. 2011. Aplikasi Analisis Multivariate dengan Program IBM SPSS 19. Semarang: Badan Penerbit Universitas Diponegoro.

Krismiaji. 2010. Sistem Informasi Akuntansi. Yogyakarta: UPP AMP YKPN.

Mulyadi. 2008. Sistem Akuntansi. Jakarta: Salemba Empat.

Nur Indriantoro dan Bambang Supeno. 2009, Metode Penelitian Bisnis. Yogyakarta: Badan Penerbit Fakultas Ekonomi.

Rama, Dasaratha V. dan Frederick L. Jones. 2011. Sistem Informasi Akuntansi: Accounting Information System. Jakarta: Salemba Empat.

Rukhyat Kosasih. 2008. Auditing Prinsip dan Prosedur, Surabaya: Papala.

Sugiyono, 2010. Metode Penelitian Bisnis, Jakarta: Alfabeta.

Suharsimi Arikunto. 2010. Prosedur Penelitian, Jakarta: Rineka Cipta.

Suprajadi, Lusy. 2009. Teori Kecurangan, Fraud Awareness, Dan Metedologi Untuk Mendeteksi Kecurangan Pelaporan Keuangan, Bandung: Jurnal, Volume 13, Nomor 2.

Trihendradi, C. 2011. Langkah Mudah Melakukan Analisis Statistik SPSS 19, Yogyakarta: Andi.

Zaki Baridwan. 2009. Sistem Akuntansi Penyusunan Prosedur dan Metode. Yogyakarta: Badan Penerbit Fakultas Ekonomi 